\title{
Homonymy, Polysemy and Zero Derivation in the English-Macedonian Context
}

\author{
Marjana Vaneva, PhD \\ University American College Skopje, School of Foreign Languages \\ Email: vaneva@uacs.edu.mk
}

Doi:10.5901/mjss.2013.v4n3p77

\begin{abstract}
Since the notions of homonymy, polysemy and zero derivation share some characteristics that make them similar, while they are independent language phenomena that linguistically distinguish from one another; this paper aims to explain the features of these three concepts, by defining them individually, giving their similarities, contrasting the two types of semantic relation: homonymy and polysemy on one side, and the word formation process of zero derivation on the other. The analysis attempts to explain the reason for the confusion they cause due to the same form of the word, by distinctly clarifying the semantic moment behind the concerned lexemes. In addition to the meaning, and regarding zero derivation, the lexical category is taken as a crucial factor because in all cases the form is the same, the words can belong to the same word class, but have related meanings when talking about polysemy, completely different meanings when homonymy is in question, and expanded meaning in zero derivation, while in this word formation process on which the analysis is particularly focused, the change of the word class is obligatory. The existence of these concepts in linguistics is illustrated with examples from English and from Macedonian, taken as language structures where the three processes are equally present. The semantic transfer - the transfer of the meaning between the lexemes is used as a method in the analysis of these processes.
\end{abstract}

Keywords: form, meaning, lexical category

\section{Introduction}

The notions of homonymy and polysemy are very often explained along with the process of zero derivation in order to determine the difference between these two different concepts, and especially because of their specific difference regarding zero derivation. Hence, in order to be able to talk and write about derivation with a zero affix, it is recommended that a difference between polysemy and homonymy is made, which will be based on the distance, that is, on the closeness and connectedness of the meanings among the ambiguous words. But, one can certainly witness that it is not always easy to make such distinction since there is no universal criterion, and this issue stirs theoretical discussion.

Namely, the lexicon contains information about the meanings of relevant words which is important for proper sentence interpretation, thus it is the lexicon that is consulted as a source to determine the word meaning in the framework of grammar. This tendency to study the meaning had existed long before linguistics obtained its independent status and became a separate discipline. Such efforts had started with Plato and Aristotle in Old Greece, and existed all up to Wittgenstein and Russell in the last century. Of all reflections, Wittgenstein's proved to be the most acceptable; when he says that 'the meaning of the language expression is determined by its use in the language community'. This brings us to the comprehension that the meaning of language expressions can be clarified with speech analysis and the context in which it is used. As a matter of fact, in order for the meaning to be determined, the semantic and lexical relations are important, which include words and expressions, and, the most significant of all are the relations of homonymy and polysemy because these lead to lexical polysemy in the language. This is due to the fact that one and the same form develops two or more meanings which, on the other hand, are similar or completely different, so that polysems and homonyms are distinguished.

Considering that all these three concepts have been much analysed in English, besides English, we will use Macedonian examples in order to make better illustration.

For example:

Tој ја занемари косата. (коса: 1. 'коса на глава'; 2. 'коса за косење') 
If we have only this sentence at our disposal, then it can be considered to be polysemous, because we don't know the exact interpretation of the word koca. But, the confusion will be resolved and polysemy will disappear provided we hear the following sentence:

Од неочекуваната глетка нејзе ѝ се крена косата на главата.

With this, we definitely know that here we are referring to 'коса на глава'.

In the process of communication it is very important to detect the polysemy because there is successful communication when both the speaker and the hearer will find one and the same meaning in one potentially polysemous expression.

\section{Homonymy and polysemy in the English-Macedonian context}

The difference between homonymy and polysemy isn't that huge, but it has a pedagogical-methodological character. Homonyms are words that are spelt and pronounced the same; or only spelt in the same way; or only pronounced the same, but they have completely different meanings, while polysems definitely have a same form, and more sub variants of one and the same meaning, that is, they have related meanings. Yet, besides this definition, sometimes it is difficult to distinguish between these two notions, in which case the polysems can obtain different newly acclaimed meanings and thus be treated as homonyms. In the case with polysemy, the different meanings are sufficiently closely connected so as to be regarded as one lexeme with two different interpretations. This connection is located inside the semantic form of a lexeme and is therefore subject to semantic analysis. On the other hand, in the case with homonymy, the two meanings are so far from each other that these words are treated as two different lexemes, but then the identical form is accidental. Therefore, there is no morphological connection between the words that are being analysed. Namely, the polysemy means existence of more than one semantic specification, while homonymy - existence of more than one morphological specification sharing the same phonological and graphic form (Leech, 1981, p. 224-229).

These closely connected lexical relations are subject of study of lexicology that aims to differentiate between them, and the lexicography to correctly order the lexemes in a given language. The polysemy exists in several languages, but the homonymy is far more characteristic of English than of Macedonian due to the analytic character and the dominant number of one-root words in the English language structure. Otherwise, in favour of the big number of polysems, statistics shows that the greater the word frequency, the bigger the number of variants that make its semantic structure; thus, meaning the greater its polysemy is.

By using right criteria for understanding the difference between homonymy and polysemy, the lexicographer immensely helps the user in searching for the right word. In doing so, the etymological character is the key criterion according to which a given lexeme will be treated as a homonym, in which case it is represented through more than one entry word, or as a polysemy when various semantic variants are listed under one and the same entry word. This implies that the elements with same forms, same history and etymology, but different meanings are treated as polysems by lexicography and those with different etymology are homonyms.

The difference between homonymy and polysemy further lies in the extent to which the meanings of the discussed lexemes are connected, and there are two answers to what we mean when we talk about connection: historical and psychological, which don't have to coincide. Actually, both meanings are historically connected if they originate from the same source, or if one meaning is derived from the other, whereas their connection is psychological when the contemporary speakers intuitively feel that those meanings are connected and thus suppose that they are actually different uses of one and the same word. This allows us to say that two lexical meanings are psychologically connected if the speaker can connect them with lexical rules, that is to say, with the rule of metaphoric transfer. This definition becomes grounded with the fact that lexical rules have psychological reality and they are part of the native speaker's linguistic competence (Leech, 1974, p. 218-229).

In linguistics, when the meaning is a criterion for classification, there are different problems, especially in, the always unfavourable, marginal cases. This results from the fact that meaning is a subjective category, something to which a strict criterion cannot apply. Thus, it is no wonder that it is difficult, sometimes even impossible, to clearly differentiate between homonymy and polysemy. In the lexicographic tradition, the marginal cases between these two notions were explained according to historical criteria: if in an earlier phase from the history of that language the polysemous word had had different forms that corresponded with its different meanings in the contemporary language, then it was considered to be a homonym, but if those different meanings had developed from the original form of that word in the given language, then it was treated as polysemy and was recorded in the dictionary only once (Stefanovski, 2006, p. 91). 

example:

The word lexeme helps us to analyse polysemy - the existence of several meanings in separate words. For

fair $\mathrm{n}$. (as a collection of outdoor entertainments, stalls)

fair adj.1 (as good, acceptable)

fair adj.2 (as light in colour of the skin or hair).

This lexeme has three related meanings for one and the same word form. This also refers to the meanings of the following lexeme:

lap 1 n./v. (as in a race)

lap $2 \mathrm{v}$. (as in 'the cat laps the milk')

lap $3 \mathrm{n}$. (as in 'sit on my lap').

The same case is in the Macedonian language too, where if the different word meanings are clearly related, that is, derived from mutually basic meanings by metaphoric transfer, then polysemy is in question. Such are the following examples:

лист (на гранка, во книга, вид риба) meaning (on a branch, in a book, a type of fish) or

крило (на птица, авион, прозорец, зграда, во фудбал) meaning (of a bird, plane, window, building, in football).

These polysems are characterized with a specific intuitive and metaphoric connection which is common for both words; actually, the word has two or more meanings that are at least a little connected.

On the other hand, the two or more different and unconnected meanings refer to homonyms that are created quite accidentally, with no connection and motivation among them. This is illustrated with the following words in English:

bank - a financial institution; side of a river or a stream

club - a social organization; a blunt weapon

pen - a writing instrument; a small cage

bat - a winged rodent; a piece of equipment used in baseball

stick - a piece of wood; adhere

Also, in Macedonian, the situation is very similar:

кука (fem. n.; imperf. v.)

јасен (adj.; neut. n.)

скара (fem. n.; perf. v.)

nod (masc.n.; adv.)

od (prep.; neut. n.).

In the lexicographic processing of homonymy in Macedonian, the description of the difference between lexical and grammatical homonymy appears to be a problem. Regarding this, the lexicographic solutions are different. Namely, in the English language it is a practice that in one entry item more words with identical form are included, with similar lexical meaning, even when they belong to different word groups. Due to the analytical and to the monosyllabic character of English which offer excellent opportunity for zero derivation, the English lexicographers claim that one and the same word can belong to different word groups. Since these words differ grammatically considering their belonging to a particular part of speech, and they have the smallest common lexical denominator, they are treated as grammatical homonyms, and lexical polysems. In Macedonian, on the other hand, this is different because one and the same language form cannot belong to different parts of speech.

According to Stefanovski (2006, p. 93), homonymy is a serious problem in lexicology and lexicography because, taking into consideration what English lexicographers think, it is very possible for one word to appear in different word groups. This reasoning already approaches the third notion that is also our subject of study here, and is one of the most distinguished processes in the contemporary English language - zero derivation.

\section{Zero derivation in the English-Macedonian context}

Zero derivation differs from homonymy and polysemy by the fact that from a given lexical item, by zero affix, and by retaining and expanding the meaning, one or more lexemes are derived and they belong to different lexical categories. If in the case with homonymy the form is the same and the meaning is different; in the examples with polysemy the form is the same and the meaning is similar or connected; in the case with zero derivation, a new moment occurs when, except for the identical form and the expanded meaning, it is obligatory for the lexeme to be used as another type of word so that we analyse the process of zero derivation of a certain lexeme. Thus, in English the word list is a verb in the sentence: 
and a noun in

He gave me a long list of his troubles.

This results from the definition of analytical languages, that is, to change the part of speech of the lexeme, and to derive a new lexeme without morphological changes.

But, for the synthetic languages, like Macedonian, another definition applies when it comes to the process of zero derivation: when by retaining the form, it is allowed to add, replace, and drop inflectional suffixes. This is how it is illustrated in Macedonian:

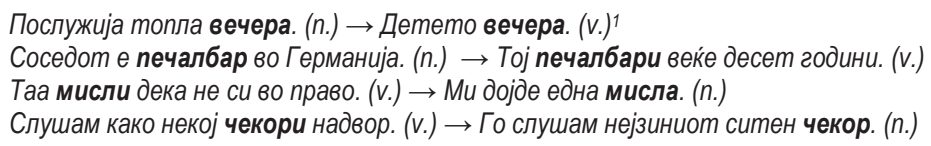

This shows that contrary to the example in English when there is complete overlap in the form of the lexeme as a noun and as a verb, in the example with Macedonian, inflection has a great role; here it is absolutely necessary to intervene in the form of the source lexeme that becomes participant in the process of zero derivation when the lexeme is the same or when the form formation suffix is replaced, but also when a suffix is added to the basis or it will be taken from the basis, thus changing only the form of the analysed lexeme. In any case, when the form is maintained or changed, when there is semantic similarity between the lexemes and those with the same form belong to different word groups, then, without doubt, zero derivation is in question, provided we find context that will support the zero derivational role of the words.

Namely, if we want to put zero derivation distinctly apart from the processes it is very often confused with, or at least contrasted with, we ought to more closely explain word formation as a discipline. Kiril Koneski (Кирил Конески, 1995) elaborates on word formation as a process in Macedonian and maintains that one's language's vocabulary is susceptible to continuous changes; some words become old, so that they stop being used, because the objects and the notions that they have denoted also disappear, while others are being formed to denote new concepts that modern life brings with itself. As a discipline, word formation studies the analysis and description of word formation motivated words, that is, words which are by form (spoken and written) and by content (meaning) conditioned by other same-rooted words in the language. This means that word formation is a living process of forming new words in the language, and word formation as part of the language science studies this process. A direct subject of study of this discipline is the word, actually, its structure in correlation with another, similar word connected by the relation of motivation. But, word formation does not only discover the ways and means for forming words; in addition, it classifies the motivated words according to their general features and determines the word formation categories and types, as well as their presence in the language. Thus, this discipline discovers the whole word formation language system and determines the norms of its functioning.

Traditionally speaking, the word formation process is included in grammar, more precisely in morphology, because both morphology and derivation study the words' structure, but the difference is in the way this structure is treated. Morphologically, the words are studied as given lexemes in terms of their morphemic structure and their segmentation to the smallest semantic items, while, on the other hand, word formation studies the word structure from the aspect of their formation in relation with the words from which they have been formed, discovers the word formation meanings, as well as the means for their expression. Therefore, the word formation goes beyond the morphology domain and also includes the affix-less ways for word formation.

The newer trends in language study distinguish word formation as a separate linguistic discipline right due to its intermediate place between morphology and lexicology. Depending on what types of changes have been made, what word formation means and procedures are used when deriving one word from another, there are four basic ways of word formation: lexico-semantic, lexico-syntactic, morpho-syntactic and morphological or affixal.

a. The first type is semantic word formation, which means developing new meaning in the already existing vocal complex.

b. The second type is called compounding, when compound words are directly formed from word combinations.

c. The third type is known as syntactic conversion, when new lexemes are formed by word's transformation from one to another word class without adding word formation elements. Thus, the new word takes over the

\footnotetext{
${ }^{1}$ For the lexemes in this paper's examples, the Macedonian and the English dictionaries that are fully referenced at the end of the paper have been consulted respectively.
} 
semantic-grammar features of the word class whose member it becomes. On the basis of the fact into which word class the word is zero derived during lexicalization, the following notions can be distinguished:

- substantivisation (a word that is not noun becomes a member of the noun group),

- adjectivisation (certain words become members of the adjectival word class),

- verbalisation (words become members of the verbal word class), and

- adverbalisation (deriving adverbs from other word classes), that is, adverbalisation, noun, adjectival, verbal and other composites.

d. The last, morphological (affixal) type of word formation refers to forming new words on basis of the existent ones by using word formation morphemes or affixes. This is, actually, the most productive way of word formation not only in Macedonian, but also in the other Slavic languages.

As far as the lexemes are concerned, they are different according to the function in the word structure, that is, in the structure of the word forms. Some refer to the lexical meaning of the word and have a semantic function, while others refer to the grammatical meaning and have grammatical function. In determining the relation between word formation and form formation, it is the functional criterion that is important according to which word formation concerns itself with the problems of forming motivated lexemes, while form formation deals with the problems of forming word forms.

As a process, in linguistic literature, zero derivation has been named differently and all those names imply different interpretations. Bauer (1983, p. 32) claims that conversion means changing the word class by losing the formal identity, that is, the lexeme finishes its existence in its basic class, but in our case, it is not about this, since the word with the same form exists in both the first, basic, and in the second, derived category. Thus, the name conversion is inappropriate for use regarding the fact that in this phenomenon nothing is converted, because the basic word continues its existence along with the new lexeme. Parallel to this name, Marchand, Adams and Quirk suggest the term functional shift when the word receives function different from its usual one, but this is not acceptable either since it implies that a new lexeme is not formed, it is rather the same lexeme with another function. Furthermore, the name root formation is not always adequate either because this process can include not only root (basic) words, but also words that contain affixes and compounds like audition n./v. and featherbed n./v. Another, very commonly used name for this notion is unmarked change of the word class, something that is discussed as conversion or nominalization when cognitive-linguistic interpretation is given of the notions that are of our primary concern here.

Finally, the name that we ascribe to this phenomenon is zero derivation, which means transfer of the word from one to another word class without adding word formation means, but by using a zero suffix that can be neither seen nor heard. This name implies that we do have derivation, that is, formation of a word in another lexical category, but with a zero affix that although not seen or heard has grammatical meaning, while there is semantic dependence of one word on the other. Yet, this terminology does not allow us to distinguish this case of change from that in which there is change of sound as food $\mathrm{n}$. - feed v., since this is not a case of the same word form, but even besides that, it belongs to transformation with a zero affix. Marchand's stand (1969) is that our process is a functional phenomenon that concerns only the content aspect of the linguistic sign and corresponds with zero derivation; in order words it undoubtedly means adding invisible suffix.

From all these terms that we have explained, the name conversion is the one that is most closely used with the phrase that we have chosen for these purposes - zero derivation, since its use implies deriving a word from one category into another which results in change of lexical, and also paradigmatic and syntactic functions.

The fact that one of the two words - the derived one - has semantically more complex structure than the other the basic one - is the reason for Hansen's argument (Bauer and Valera 2005, p. 138) when he says that the interpretation of zero derivation as a simple transposition into another lexical category, actually as a syntactic phenomenon is inadequate: the change of meaning that accompanies zero derivation usually affects the semantic and syntactic occurrence of the resulting word and this is considered to be an indirect evidence for the occurrence of a new, derived word which is outside of the syntactic domain, as the change of grammatical paradigm is understood as an additional marker of the independent status of the newly formed word. It seems that the character of the unmarked change of the word class is controversial when asking the crucial question: if it should be treated as a process of zero derivation or not.

If answered negatively, this notion means change of the syntactic function of the word, and then terms used for its determining are conversion, transposition or partial conversion.

If answered positively, then this is a process of zero derivation and, in this case, either the existence of a zero morpheme is introduced, as we claim, or the paradigm change of the respective word is considered to be a marker of the zero derivational process. The terms used for this process by the proponents of this statement are zero derivation or paradigm change. 
Actually, the names functional shift or transposition imply that the process in question concerns the usage, not zero derivation, which leads us to controversy because by accepting the name functional shift we admit that one and the same word simultaneously belongs to several lexical categories. But, we agree with the Russian linguists when they say that it is not possible for one word to belong to several lexical categories at the same time, because it contradicts with the basic definition of the word as a system of forms, which implies that the notion natural class is crucial to us. It is the direction that we follow in the process of zero derivation and the inevitable change of the lexical category or subcategory that happens when witnessing the formation of a new lexeme.

From all these suggested terms up to now, we prefer the term zero derivation, phenomenon that has become of interest to many linguists, who have occupied themselves with the nature of this concept.

Some of the most prominent names that explore this process as a derivational one will be briefly analysed in a chronological order :

- Jackson (1980, p. 109-110) maintains that zero derivation is analogous to suffixation, by explaining that the verb release corresponds with the noun release as in the example:

They released him. $\rightarrow$ They ordered his release.

But, this relation zero derivation-suffixation is different from the one between the verb acquit and the noun acquittal which, on the other hand, is an example of suffixal derivation:

They acquitted him. and

They ordered his acquittal.

- $\quad$ Bauer (1983, p. 32) has already been mentioned with the stand that this process is extremely productive for forming new words in English because, due to the loss of inflectional suffixes, one word can belong to several categories.

- Hurford and Heasley (1983, p. 206) claim that when we analyse the derivational processes, we ought to take into consideration the fact that it is not one, but three processes:

morphological, when the form changes by adding prefixes or suffixes,

syntactic, when the part of speech changes, and

semantic, when a new meaning is developed.

- $\quad$ Quirk, Greenbaum, Leech and Svartvik (1985, p. 2558) treat zero derivation as a process of derivation, that is word formation, and they think the semantic dependence of one lexeme on the other is crucial for the understanding of this concept.

- Arnold (1986, p. 153-154) believes that the development of this process is due to the absence of morphological elements or formal signs that will mark the word class to which the lexeme belongs. He points out that forming new word is a result of contextual use, thus saying that zero derivation is impossible outside of context, that is, no isolated word can be created by zero derivation.

- Plag $(2003$, p. 12) thinks that zero derivation is a way of forming words without obvious marking, which he claims does exist in this process but isn't obvious. Therefore, according to him, it is the form that is zero, and definitely not the meaning. The form is zero because there is no derivational intervention, but only inflectional suffixes are used, to make the new lexeme correspond with the demands of the lexical category whose member it becomes after the process.

For example:

They will send an invoice for the goods.(n.) $\rightarrow$ The company hasn't invoiced us.(v.)

He pushed the door. (v.) $\rightarrow$ The car won't start - I need a push. (n.)

They were too busy to enjoy. (adj.) $\rightarrow$ They busy themselves with their new home.(v.)

I usually awake at night.(v.) $\rightarrow$ The noise keeps me awake at night.(adj.)

We had an early lunch. (adj.) $\rightarrow$ I was planning to finish work early today.(adv.)

This is absolutely the same in Macedonian:

Поставија топла вечера. (n.) $\rightarrow$ Девојчето вечера во собата.(v.)

Тој мисли логично.(v.) $\rightarrow$ Оторрли ја таа лоша мисла.(n.)

Ова е чист случај.(adj.) $\rightarrow$ Чистачката го чисти станот.(v.)

Војниците отидоа на нова задача.(v.) $\rightarrow$ Војниците се отидени на нова задача.(adj.)

Актерот имаше емоционално обраќање. (adj.) $\rightarrow$ Актерот емоционално им се обрати на присутните.(adv.)

The examples show that in English zero derivation is mainly prototypical, with very few inflections, but when they are added, they only denote the grammatical categories that the lexeme needs in order to be realized in the language 
context. Those exponents of the grammatical categories are: for number (plural) - $-s$, for person (third person singular present simple tense) - -s, for tense (past simple) - -ed, for present participle - -ing, for past participle - -en, for Genitive - 's, as well as for comparative and superlative forms of the adjectives - -er, and -est. Therefore, due to the small number of inflections in this language, zero derivation is analysed at a word level and we very often witness absolute formal identity between the lexemes on both sides of the process, as in the above mentioned example with push. When inflectional suffixes are added, they serve the process just by 'assimilating' the newly formed lexeme in the new category, and accommodating it by adding grammatical suffixes imposed by the context. An example of this is invoice.

On the other hand, in Macedonian like in the other inflectional, synthetic languages, these form formation or inflectional suffixes are of crucial importance for the process, because, in their own inflectional, certainly not in derivational aspect, when added to the word basis, they make the new lexeme overlap with the source element and thus illustrate the process of zero derivation. This explanation is seen in the case with отидени, when what matters is that both lexemes have the same motivating basis and they are derivationally identical, so that only inflectional material is used. The other Macedonian examples that have been previously listed in the last group all mirror the process of zero derivation without inflections, when the realization of the lexeme and its place in the context structure do not impose such interventions. The structures with вечера and the others show the formal overlap.

\section{Concluding remarks}

In both languages, English and Macedonian, the difference between homonymy and polysemy taken together on one side, and zero derivation on the other, is clearly established, so that it is emphasized that attention should be paid to the word class and to the meaning, given that the form between the lexemes is the same. Therefore, in the case of polysemy we deal with the same form, the same part of speech and related meaning; when talking about homonymy the form can be the same or completely different, the part of speech may not be the same, but the meaning is absolutely different, while in zero derivation we encounter completely different situation. Not only because of the distinguishing feature of the process - the same form, similar expanded meaning, and necessarily different lexical category, but also because of its specific characteristic in Macedonian.

Namely, as seen in this paper, the process of zero derivation is lexico-grammatical and syntactic process connected with both derivation and inflection. The lexical part is evident in the lexical changes in the word and with formation of a new lexeme, while the grammatical or syntactic moment is present through the different function the element has depending on its position in the sentence. Of course, there is derivation in this case, since as the name says - zero derivation - there is formation or derivation of a new lexeme and the process is zero, because an invisible or zero affix is used. The inflectional part of the process is especially significant in Macedonian because in most cases it is the inflection that should be credited for zero deriving a new lexeme. In English, the explanation for the existence of this process without inflection is that the inflectional system of this language, as analytical, is poorer compared to Macedonian, and there are not that many inflectional suffixes that can contribute to the process. But, the thing is that even if there were more inflections in the English language, there is almost no need to take them into consideration when analyzing the productivity of the process (except when we are interested in comparing the inflectional systems of both languages), since only with the overlap in form and with the very few inflections, English manages to provide us with an astonishing number of examples of zero derivation.

All things considered, it is hoped that the definition and the study of the three processes in English and in Macedonian presented in this paper will contribute to their clear identification and distinction in future.

\section{References}

Arnold, I.V. (1986). The English Word. Москва: Высшая школа.

Bauer, L. (1983). English Word-Formation. Cambridge: Cambridge University Press.

Bauer, L. \& Valera, S. (2005). Approaches to Conversion / Zero-Derivation. Münster: Waxmann Publishing Co.

Hornby, A.S. (1995). Oxford Advanced Learner's Dictionary. (5th ed.). Jonathan Crowther (Ed.), Oxford: Oxford University Press.

Hurford, J.R. \& Heasley, B. (1983). Semantics: a coursebook. Cambridge: Cambridge University Press.

Jackson, H. (1980). Analyzing English: An Introduction to descriptive linguistics. Oxford: Pergamon Press.

Конески, К. (1995). Зборообразувањето во современиот македонски јазик. Скопје: Бона.

Leech, G. (1974). Semantics: The Study of Meaning. London: Penguin Group.

Marchand, H. (1969). The Categories and Types of Present-day English Word formation. 2nd edition. Munich: Beck.

Plag, I. (2003). Word-Formation in English. Cambridge: Cambridge University Press. 
Quirk, R,; Greenbaum, S.; Leech, G. \& Svartvik, J. (1985). A Comprehensive Grammar of the English Language. London and New York: Longman.

Речник на македонскиот јазик со српскохрватски толкувања. (1994). том: I, II, III,

редактор Блаже Конески. Скопје: Детска радост.

Речник на македонската народна поезија. $(1983,1987,1993,2001)$. том: I, II, III, IV. Скопје: Институт за македонски јазик „Крсте Мисирков"

Stefanovski, Lj. (2006). English Lexicology: A coursebook. Skopje: DataPons.

The New Oxford Dictionary of English. (1998). (1st ed.). J. Pearsall, \& P. Hans, Oxford: Oxford University Press.

The Oxford American College Dictionary. (2002). New York: Oxford University Press.

Толковен речник на македонскиот јазик. (2003). том: I, II, III, IV, раководител на проектот д-р Снежана Велковска, Скопје: Институт за македонски јазик „Крсте Мисирков”. 